\title{
The new revisionists and the history of U.S. higher education
}

\author{
ROBERT T. BLACKBURN ${ }^{1} \&$ CLIFTON F. CONRAD ${ }^{2}$ \\ ${ }^{I}$ Center for the Study of Higher \& Postsecondary Education, University of Michigan, Ann \\ Arbor, MI, USA; ${ }^{2}$ Center for the Study of Higher Education, University of Arizona, Tucson, \\ $A Z, U S A$
}

\begin{abstract}
This paper presents the traditional history of the development of higher education in the United States, especially during the nineteenth century, and then examines at the findings of the new revisionist historians regarding the content of the curriculum, the mode of instruction, the believed theory of learning, the quality of college leadership, and their egalitarianism. While the revisionists' evidence discredits some of the traditional interpretation of events, some of their data are questionable and some of their methods are found wanting. This paper focuses on the implications of the disparities and advances a thesis.
\end{abstract}

Over the past decade a number of historical pieces have contained evidence and explanations contrary to those found in the traditional histories of U.S. higher education. More often in articles and dissertations than in books, vital issues have been broached about the rigidity of the curriculum in the 19th century and its lack of responsiveness to societal needs; about whether recitation as the standard mode of instruction stifled learning; about the soundness of the psychology of learning on which the curriculum and pedagogy were based; about the quality of institutional leadership; and even about the nondemocratic nature of the entire enterprise. As yet, the traditionalists have not responded to the questions that revisionist historians have raised.

However, no revisionist has yet produced a comprehensive history based on new evidence. At the same time, with the exception of some brief reviews, there have been no systematic critiques of the revisionists' evidence and explanations. This hiatus is most unfortunate. The present condition of higher education has been shaped on the anvil of the past just as the future will be determined by actions taken today. Today, especially, shortfalls of students and dollars precipitate critical decisions that shape the long-term futures of our college and universities. Historians can provide us with the understandings which increases the likelihood of informed action.

Of course, for historians to be successful in their inquiries, a dependable knowledge base must be established. Consequently, it is important to examine dispassionately both traditionalists' and revisionists' works. They cannot both be correct. However, both can both be in error. Higher education needs to know its development in the United States and to understand the factors which explain its evolution. 
This paper begins this task. First we look at the traditional argument for the failure of the antebellum college and the data on which these historians build their case. Then we examine the counter evidence the revisionists have advanced - its reliability, validity, and representativeness - and critique selections of two revisionists. ${ }^{1}$ The paper closes with a discussion of the current state of the debate and the advancement of an hypothesis.

\section{The traditionalist view}

In brief, the traditionalist position with respect to higher education in the United States holds that the colleges before the Civil War were failures, even those that survived. They failed to respond to the contemporary needs of individuals and of society. Colleges exist to develop people intellectually so they become creators of knowledge and solvers of problems both natural and social. Colleges exist to prepare people for vocations that society needs. Antebellum colleges failed to accomplish these purposes for several reasons: they adhered to an inappropriate curriculum (the classical curriculum), used an ineffective mode of instruction, subscribed to a false psychology of learning, suffered under poor leadership (presidents), and remained elitist. That is why, in the main, colleges failed to flourish and attracted but a very small percent age of the population. Moreover, according to the traditionists, this is why large numbers of them eventually closed their doors.

\section{Curriculum and instruction}

More than one historian claims the curriculum was all but invariant across the nation, at least through the antebellum period. At the turn of the 20 th century, Flexner wrote (1908:30-31):

Forty years ago [in 1867] the Bachelor's degree conveyed a specific and practically invariable meaning. There was one narrow path to academic confirmation; every candidate had to traverse it. Perhaps the college graduate did not expect to be a lawyer or a clergyman; he had, however, to be content with an education strictly relevant only to these two learned callings. A cultivated man was one who, whatever ignorance or limitations in other directions, had enjoyed a liberal education of this description. The classics were the backbone of the college curriculum; they were supplemented by the cut and dried philosophy and rhetoric then current, some mathematics and bookish science, and an occasional dip into modern literature. 
In his biography of Cornell University's founding president, Andrew D. White, Rogers quotes White's letters voicing deep dismay at how faculty were mistreated by students. He says White felt that it was the rigidity of the classical curriculum and the way that it was taught that prompted unruly student behavior. According to Rogers (1942:44):

The American college which White dreamed of reforming was poorly equipped both in physical plant and in endowments. Libraries were small, and the librarian's duty seemed more to preserve the books than to make them accessible to the students. Technical training was as yet little known, laboratories did not exist, and the whole field of science except on the theoretical side had hardly been touched. Much of the teaching in all branches was done dogmatically and with generalizations which in many cases rested on a lack of extensive investigation or careful scholarship.

Schmidt also addressed the rigidity of the curriculum and the mode of instruction. Speaking of their deleterious consequences, he wrote (1957:44):

Such a course [moral philosophy, the senior required course and most often taught by the president, a minister] and such a lecturer made up for years of dull recitation and routine translation of the dead languages.

Whatever appeal the moral philosophy course may have had for the average undergraduate, a deeper though perhaps more unpleasant impression was left by another subject of instruction. By far the largest amount of his time and effort was devoted to the ancient languages, Greek and Latin. After practically monopolizing the student's time in the freshman and sophomore years, these "classics" continued as an important part of his program almost up to graduation. Along with mathematics they were the "core curriculum," the subjects that mattered. Other things were taught, but with the exception of the senior philosophy course they were fringe subjects.

The sciences received lip service and little more. Laboratory instruction was unheard of, but the demonstrating equipment of the better institutions was probably as good as could be had at the time.

Schmidt, while noting some exceptions, viz., the University of Pennsylvania and the University of Virginia (1957:54), continues by emphasizing the stranglehold the classical curriculum had on U.S. higher education. He has the New England curriculum trailing the frontier:

From its strongholds in the east the standard classical curriculum spread west and south, keeping with the building of new colleges and marking the advance of the cultural frontier. This frontier, by the way, showed little inde- 
pendence of judgment when it came to choosing a form of higher education adapted to its needs. Whatever originality it may have displayed in fashioning economic and political institutions - a point which the successors of Frederick J. Turner are still debating - in matters of higher education, the frontier was docile and receptive to eastern ideas.

Besides promoting tedious instruction, the classical curriculum was the cause of low enrollments and serious financial straits and hence the consequent demise of many institutions. As Rudolph (1962:198) quotes Brown University's reform-minded president Francis Wayland:

I doubt whether anyone could attract a respectable number of pupils ... did it charge for tuition the fees which would be requisite to remunerate its officers [faculty] at the rate ordinarily received by other professional men. And later:

Can [a liberal education] not be made to recommend itself; so that he who wishes to obtain it shall also be willing to pay for it?

Rudolph answers this rhetorical question:

Wayland himself knew that the answer to his question was necessarily a resounding "no" as long as the American college insisted on holding rigidly to the prescribed classical course of study. Until the curriculum changed, the colleges, if they were to have students, would have to buy them.

In short, the high failure rate of institutions which has been claimed by Tewksbury derived from a sterile curriculum and a stultifying pedagogy. The classical curriculum and the recitations of ancient works met neither personal nor societal needs. And, according to traditional historians, potential students know it.

\section{Theory of learning}

Consonant with their emphasis on a rigid curriculum and a single mode of instruction, traditionalists have called attention to "faculty psychology." Proponents of the classical curriculum are said to subscribe to this theory of learning and thereby legitimize the classical curriculum. Butts and Cremin (1953:178) succinctly capture the essence of this theory:

Faculty psychology was especially important as providing the basic justification for mental discipline as the supreme method in college education and 
for giving first place to the classics, mathematics, and philosophy as the essential content of a liberal education. It was used as a bulwark against admitting new and useful studies to the college curriculum. Of all the educational statements of the time the one that most clearly illustrates the operation of the faculty psychology as the basis for mental discipline and the prescribed curriculum of intellectual studies was the Yale faculty report of 1828 which stated in the words of President Jeremiah Day: "The two great points to be gained in intellectual culture, are the discipline and furniture of the mind; expanding its powers, and storing it with knowledge."

Invoking faculty psychology as the theory of learning left no alternative to the classical curriculum and the recitation method. Veysey (1965:337ff) supports this interpretation and argues that it took the demise and replacement of faculty psychology before the university could emerge. That is, only after this "mental discipline" aim of learning was discredited, could specialization and an elective curriculum emerge. Such is the traditionalist view.

\section{The failure of leadership}

According to the traditionalists, a fourth factor contributing to the inefficacy of antebellum colleges - including the demise of some institutions and the poor health of numerous others - was inept leadership. Simply, missionary zeal proved no substitute for educational savvy. Hofstader and Metzger (1955:209-210) remark how "this multiplying and scattering of colleges was primarily the result of denominational sponsorship and sectarian competition." The title of Chapter V of their work - "The Great Retrogression" amply captures their theme. Colleges lacked leadership based on sound notions of what higher education should be. As a result, failure was less surprising than inevitable.

Nor was such ineptitude confined to the expanding West. Institutions in New England - at Hanover and New Haven - evinced the same lack of vision. Peterson (1964:81) describes the 1881 trial of Dartmouth's president.

It was a strange way for the old college to die... in the sickly phosphorescence of an alumnus's cross-examination of his president, a mathematics professor's testimony that his president was dishonest and insolent without the traces of manliness, while out in the audience the reporters scribbled their dispatches for the front pages of the Boston and New York newspapers. It was a strange death for the college and its noble ideal of harmony. 
In the case of Yale, Peterson writes:

One day in 1884 William Graham Summer and his faculty committee marched into President Noah Porter's office and informed him that they were not leaving until Yale had an elective system. Three exhausting hours later, the professors marched out with their electives. "It was a brutal procedure," one of them said, "but it was effective."

The traditionalists link the factor of poor leadership to both the curriculum and to learning theory. By holding to the irrelevant classical curriculum and subscribing to a faulty "faculty psychology" which held that exercising the mind with classical subjects was the essence of an education, presidents were destroying their own institutions.

\section{Exclusiveness}

In Rudolph's (1962:199) interpretation, another cause for the failure of the antebellum colleges lay in the elitist, undemocratic label attached to the classical curriculum. In order to obtain enough students, colleges reduced and/or waived tuition for two reasons:

One, the desire to project a more democratic image in a society that had interpreted the strength of the classical curriculum as a sign of aristocratic attachments; the other, the necessity of competing among an almost unlimited number of colleges for the rather limited number of students who could afford and who wished to avail themselves of the classical course of study.

Brubacher and Rudy (1968:155) supplement Rudolph's explanation for sparse enrollments by claiming there "was an anti-intellectualism which was rife through the New West." The hard-working pioneer was unwilling to pay taxes to support higher education.

From his perspective as an advocate of the land grant movement, Ross (1942:13) echoes this notion of exclusiveness:

It appears, then, that by the forties [1840s] the nation's chief educational need was for an adequate provision for vocational training which awaited mainly the course of economic and social evolution. Only when the limitations of primitive exploitation were sufficiently manifested could there arise class-conscious interests and movements which would compel the creation of institutions at the higher as at the lower levels adopted to popular needs 
and desires, people's colleges as the crowning feature of a democratic school system.

In summary, the traditionalists have built a case to support Tewksbury's lengthy obituary column. A fixed curriculum inappropriate to a changing society, an incorrect psychology of learning, an ineffective mode of instruction, and inept leadership - these factors stubbornly maintained colleges for an aristocratic elite that the masses largely shunned. Small wonder that the college death toll was a large one, about 81 percent according to Tewksbury (1932).

Let us now turn to the revisionist interpretation of these same developments.

\section{The revisionists' evidence}

To begin with, colleges did not die at anywhere near the rate Tewksbury claimed, especially if we disqualify "still births" and "infant deaths" - that is, "colleges" which obtained charters (which was easy to do) but never built an institution, and others that made a brief, but futile appearances. Naylor has clearly shown not only that there are errors of omission and commission in Tewksbury; there are also questionable definitions regarding the birth, survival, and death of colleges. For example, when Sack updated the census of colleges in Pennsylvania, he found the survival rate to be close to $50 \%$. In addition, if one confines the analysis to four-year colleges and does not define a two-year academy as a college, then the fatality rate drops to about 25 percent (Naylor, 1973:265-266).

Assuming Naylor's data as true (and Tewksbury's as false and misleading) and for the moment overlooking how Tewksbury's error might be derived from the cases built by traditionalists, we must next examine the perspective of the new revisionist historians. ${ }^{2}$ We now turn to the writings revisionist historians have entered into the scholarly record that address the five components of the traditionalists' case.

\section{The curriculum}

One of the principal laments of the traditional historian with respect to the dysfunctional nature of the classical curriculum was the absence of course work in science. An examination of what was actually being taught in the colleges, however, reveals there was appreciable science content in the curriculum. As Guralnick (1974:48) writes:

It is a matter of demonstrable fact that science and the antebellum Ameri- 
can college enjoyed an amicable, even a mutually profitable, relationship: the intellectual demands of science introduced to the college problems and subsequent changes which in turn led to further scientific expansion.

As for equipment, he (1974:50) reports:

Scientific apparatus at the average college increased in value from a few hundred dollars to many thousands by mid-century, and there was the building of laboratories and astronomical observatories to house the new acquisitions.

As far as faculty are concerned, as Wesleyan Guralnick found:

The School's first catalogue outlined a "partial course" for science-oriented students, and by 1836 Wesleyan had spent over $\$ 6,000$ on scientific equipment. By 1840 the faculty consisted of the president and six professors, three of them in mathematics and science. Most telling is the fact that there was no provision for formal theological training, as indeed there was not any college in the East.

Contemporary science was clearly being taught and practiced on the established campuses as well. While the initial attempts for laboratory sciences at Princeton essentially had failed by 1810 , they did revive when Joseph Henry was appointed in 1831. Benjamin Silliman gave his first scientific lectures at Yale in 1804 and Asa Gray was a contemporary at Harvard. It is true these two universities had their principal science activity in separate schools (Sheffield and Lawrence, respectively), and that Gray apparently had little interaction with students. However, it is also clear that science instruction - at least lectures and demonstrations - was taking place, and, in pedagogical modes other than recitation. In addition, the faculty were doing research in the manner that is understood today (Chisolm, 1984:183-265).

Relying on works on the history of science by Cohen, Struik, Daniels, Meier, Van Tassel and Hall, Sloan (1971) builds a strong case for the presence of science in the antebellum curriculum:

Scientific instruction. Revivalism was not universal in all colleges, but science, the second major subject area of the curriculum, was. Throughout the colonial period science had not been one of the basic components of the curriculum, but the colleges had attempted to keep abreast of latest advances in scientific discoveries and methods. By the end of the eighteenth century the college scientific curriculum had expanded immensely, new teaching methods, such as the experimental lecture, had been introduced, 
and the utility of science was a generally recognized and lauded ideal.

After the War of 1812, both the opportunities and the difficulties of scientific instruction increased rapidly. Expansion of higher education and the increase in numbers of institutions placed heavy burdens on the teaching capacities of the colleges, and the quality of scientific instruction undoubtedly suffered accordingly, or, at least, probably varied greatly from institution to institution. Nevertheless, as we shall see, there is reason to suppose that the achievements of the older institutions in maintaining high standards of science instruction and research may not have been adequately appreciated by historians of education. Demands for science instruction in the new nation, and the difficulties of providing it, were further heightened by the scientific and technical problems involved in exploration, transportation, communication, industry, agriculture, and public health. Finally, national pride, popular desire for practical knowledge, and notions of national progress and technological advance all helped to build enthusiasm for science in its many forms. And all increased the pressures on higher education.

Furthermore, science in the 19th century curriculum was not limited to men's colleges. Haddad (1980:249-261) displays the full four year curricula for New England's Mount Holyoke for 1837-1955, and for Midwestern's Oberlin in 1838, Lake Erie in 1847-48, and Western Reserve University's College for Women in 1889. While components of the classical curriculum are visible, including required mathematics and astronomy, women at single-sex Mount Holyoke were required to take botany and human physiology in their junior year and chemistry and geology in their senior year. At co-educational Oberlin, women had to take chemistry in their junior year. (Men did also, as well as anatomy and physics as freshmen.) Lake Erie was identical to Mount Holyoke (the model it selected upon opening). At the coordinate colleges at Western Reserve, men and women took physics in the second year, chemistry and physics in the third, and geology in the fourth. If they wished, they could take French and German instead of the classical languages.

At the same time, there were midwestern colleges that remained faithful to the 1828 Yale report until after the Morril Act. This 1862 federal legislation founded the agricultural and mechanical arts institutions. Until then, however, the seven evangelical colleges Findlay (1982) studied in Illinois and Indiana offered no science. Founded by ministers from Yale, their presidents were more dedicated to the classical curriculum than was the case at Yale.

In addition to science in the curriculum, Burke (1973:56-57) found the waiving of proficiency in Latin and the substitution of English as an entrance requirement:

By the 1830s the vast majority of colleges had instituted partial, English, 
and science courses, as well as waiving requirements for Latin proficiency. The short courses and the reduced academic requirements decreased the distance between those without a classical background and the liberal arts college. The professional schools followed the same path of reduced requirements and reduction of the level of necessary previous training. In order to make the educational system more accessible, the schools responded to the growing heterogeneity of cultural and technical backgrounds.

In summary, an appreciable body of evidence shows that the 19th century curriculum did not universally exclude the sciences or "modern" languages. ${ }^{3}$ In fact, just the opposite appears to have been the case. Many colleges were adjusting their curriculum to serve the needs and wishes of students and society.

\section{Instruction}

Turning to pedagogy, the evidence concerning instruction is less direct. Nonetheless, a sufficient amount exists to permit the inference that the mode of instruction had changed from the single recitation format the traditionalists claim. Three extensive studies of faculty backgrounds at different points in the 19th century show a dramatic shift from the original cleric to the 20th century academic professional. McCaughey (1974) displays the changes at Harvard at decade intervals from 1821 to 1892 . Tobias (1981) shows the Dartmouth faculty in 1851 and in 1881. And Creutz (1980) reports all faculty for every year to 1900 at the University of Michigan. In each of the cases one sees that those who were being hired were anything but ministers, persons capable of teaching only the classical curriculum. Tappan at Michigan was hiring researchers long before Veysey dates the emergence of the university in this country. These were scientists in laboratories who focused their instruction on research and often lectured to large numbers of students.

In the women's domain, Palmer's (1981) study of New York's and New England's Elmira, Vassar, Smith, and Wellesley colleges shows an acquisition of the professional faculty member that paralleled and rivaled the changing composition of their male counterparts. As was seen above with respect to the addition of science to the curriculum in Haddads' institutions, the new breed of professor was not likely to utilize only recitation as the mode of instruction, if ever.

Kennedy (1961) surveyed changes in the professoriate from 1800 to 1900 . She concluded that over this time span the professor had changed from a clergyman to a layman, a despot to a benevolent parent surrogate, an institutional member to a member of a department, a dilettante to a scientific scholar, a pedagogue to a subject matter specialist, a drill master to a lecturer, a classicist 
to a scientist, a user of single text to one who employed a wide assortment of resources, an oral examiner to a preparer of written examinations. Kennedy does not document the precise times of these changes, and no doubt they differed from place to place. More recently, Chisolm (1982) has thoroughly documented the existence of a variety of teaching methods - lecture, laboratory, and seminar - in addition to recitation in the antebellum period for five institutions (Princeton, Yale, Harvard, Amherst, and Columbia). The inference that instruction was something more and different from what the traditionalists assert is strong.

\section{Theory of learning}

The revisionists have not dealt directly with theories of learning. To what extent beliefs about how people learned affected either the curriculum or the method of teaching is not known. Barnes (1960:339) suggests that when science was introduced into the curriculum of Ohio colleges in the last half of the century, an argument used to justify its inclusion was that learning science was good for the training of the mind. His claim supports a belief in faculty psychology persisting after the Civil War.

We need to keep in mind, however, that psychology as a scientific discipline is a 20th century phenomenon. (Psychology was not even a separate department at the University of Michigan until the 1920's. Professors working in that area were members of the philosophy department.) Inquiry into how people learn was not systematically pursued as were other sciences and hence it is unlikely that views on learning theory carried the same weight as did, say, what specialties deserved addition to a course of study or to a degree sequence.

If these curriculum and pedagogical changes that were taking place disturbed some administrators because of conflicts with faculty psychology, they do not seem to have stood in the way of the majority. We suspect, but do not know, that theories of learning (then as now) were invented to fit a desired curriculum rather than vice versa. In any event, the revisionists have yet to discredit the traditionalists' claim of the negative consequences of subscribing to faculty psychology.

\section{Leadership}

Even if some of the leadership in the antebellum period was weak, even poor - and no doubt there are cases - the overall evidence suggests there must have been many agile, entrepreneurial presidents who were genuine success stories. Potts (1979:368) writes of institutions utilizing what we today call admis- 
sions counselors, persons hired to go out to potential clients and secure their application forms. Axtell (1971) considers the extensive and expanding library holdings of small colleges as evidence of an extended, research-based curriculum. In addition, there are many examples of antebellum leaders judged to be distinguished. Before Philip Lindsley at Nashville, Tennessee succumbed to the plethora of sectarian colleges built in his neighborhood that eventually drained off the student supply, his vision of the forthcoming university in the United States was clearly articulated and widely distributed (Rudolph, (1962:117-118). Horace Holley at Transylvania in Lexington, Kentucky enjoyed an international reputation (Borrowman, 1961). And Eliphat Nott's innovations of parallel course of study in the sciences, and his leadership on the decent treatment of students led Union College in New York to become the third largest institution in the country by 1829 and the second largest by 1839 (Rudolph, 1962:107-108, 114).

Also, there are instances of colleges that were founded in one location and then moved to another town where that city would provide land and money to have the college in its midst - local boosterism (Dominick, 1986). The presence of a college in town was good for status and good for business. (The process is not too different in kind from a city today building a sports arena with the aim of having a champion professional team within its boundaries.)

These may not all be examples of good educational leadership in the sense of presidents issuing thoughtful philosophical commentaries on the condition of higher education in the United States and what needed to be done next but then there have never been an abundant supply of such presidents at any time in history. These activities are, however, instances that support the inference that there were presidents building colleges - acquiring resources, recruiting students, and expanding their operation - all indicators of effective leadership.

\section{Exclusiveness}

That the colleges only took in the elite is the position of the traditionalists. The evidence, however, fails to support this claim, especially after 1800. In a section on "Egalitarian Trends," Potts $(1977,1981)$ examines work by Haddock and data on Franklin College. His judgment is expressed below:

Contemporary observations and quantitative data collected during the last decade support the related argument that this increased proportion of students from the middle and lower ranges of the middle class was large enough to be a distinguishing characteristic of antebellum higher education. "Little colleges," a Southern writer noted in the mid-1840's, "are the means of af- 
fording liberal education to numerous youth ... within forty miles of [their] walls, who would never go to Cambridge [Massachusetts]." Geographical proximity and modest fees were especially advantageous for families of modest means. "Men with their thousands," commented a midwestern newspaper, "can send their sons where they please; but men with only their hundreds must have a place near home, and where expenses will be at least reasonable." A pamphlet published in Boston just before mid-century contained the estimate that a "full three-fourths of the members of the country colleges are from families with small means," families described by a midwestern college president as those with "small but well cultivated farms" and "economical shops."

Allmendinger, Angelo, and Burke support this contention. For example, Allmendinger's (1975) inspection of the 1800-1860 graduates of a set of New England colleges (Amherst, Dartmouth, and six others) finds a large number of youths from poor families (from the one community he studied in detail). Large families and shrinking farms simply produced a "glut of young men" who had nothing to do at home. The alternatives were going to the city, west, or to college, aristocratic classical curriculum or not. ${ }^{4}$

As for the latter part of the century, Angelo's (1983) data on the social background of students at the University of Pennsylvania and at Temple University reveal anything but a homogeneous slice of upper class society. The numbers of low white-collar and blue-collar students were appreciable. Despite some questionable comparisons that are made, it is clear that Penn was hardly the homogeneous Ivy League elitist institution that Veysey claims. Burke (1982), as well, presents extensive data showing a student social mix far greater than the traditionalists have claimed.

Whether the revisionists data of student backgrounds proves that the colleges were aristocratic or not is another matter. The less privileged may have attended college for any of a number of reasons, in spite of discrimination they may have suffered. (Like blacks today going to northern universities which still have racist practices, they may have wanted the education, or the degree, or social mobility. The reasons can be many, and multiple.) In any event, many institutions had a heterogeneous student body.

In short, the un-/anti-democratic nature of the classical curriculum is an inadequate, and probably erroneous, explanation for college failures and for accounting for the course of higher education in the 19th century. However, before considering the implications of this new evidence, let us examine the quality of the evidence of two major revisionists. 


\section{The work of the revisionists}

The revisionists have assembled an impressive array of evidence that seriously challenges the traditional story of the development of higher education in the United States. The traditionalists have not as yet responded to the critique of their works. In fact, there has been scant critical attention given to the revisionists' manuscripts by anyone (in or out of their camp). This section looks at two authors - Angelo and Burke - and examines parts of their publications. These two include more quantitative analysis than do most others.

With regard to the issue of access for youth outside the social elite, Angelo deals with alumni from two universities in Philadelphia - Penn and Temple - during the last quarter of the 19th century and the first third of this one. Samples are drawn, but we are not told either why (to reduce the labor required?) or, and more seriously, how (random?). If not randomly drawn, then was the sample random within specified strata (by curriculum, since this becomes an important variable for the author) $?^{5}$ The reader does not know.

Besides failing to inform the reader of these critical matters which affect the validity of any inference made, for some unstated reason the groups of years (the time intervals) are not divided into equal lengths but rather run $6,7,7$, $6,6,5,6,6,4,5,5$ years each between 1873 and 1935. Despite their unequal spans, these intervals are plotted on the graphs with equal distances between each set, as if the temporal distance between successive points was constant. While the time span differences are not great numerically, they are on a percentage basis. Would there have been differences in the findings if the expected constant intervals had been used? There is no way for the reader to answer this question and hence doubts about the findings are raised.

Next, the author has plotted the data on semi-log paper with the number of degrees reflected on the $\log$ (y-axis) scale. This choice would be a proper one for testing an hypothesis of an exponential relationship between y (number of graduates) and $\mathrm{x}$ (the passage of time). However, such a test is not the purpose here. What Angelo provides is a series of points connected by lines which produce peaks and valleys. On log paper, neither have absolute nor percentage equivalences except in rare instances when the number of graduates are identical. At the same time, the author spends a considerable portion of his effort accounting for rises and falls, ones that are of not equal magnitude, and, supposedly, equal social significance.

This questionable display of data is aggravated by the author's failure to test for the statistical significance of the differences between successive age periods. Each is treated as if the differences were consequential. Yet in many instances, if not all, the interval changes could be nothing more than random fluctuations about some (unknown) mean, i.e., the differences could have occurred by chance sampling errors (at some accepted level of significance, say, $\mathrm{p}<0.05$ ). 
Such methodological deficiencies cast doubt on any and all inferences drawn from the data. We may wish to believe the author's conclusions. They may well be true. However, they are not based on accepted research canons and hence have not been properly supported.

Different but related problems surface in Burke's work. ${ }^{6}$ To begin with, the accuracy of his counting of institutions has not been established. (The same reservation holds for Naylor's calculations.) In fact, Herbst (1983:484-485) has already found inconsistencies between some of his historical records of institutional existence and Burke's. ${ }^{7}$ The number of discrepancies and the reasons for them are unknown but need to be dealt with before causal inferences are introduced.

Second, in dealing with enrollments in the antebellum period (pp. 53-63), numerical data are presented for the onset of successive decades in order to prove that, contrary to the claims of Wayland that enrollments in liberal arts colleges had declined in the antebellum period, enrollments had in fact increased. "The percentage of the young white males of the country who entered colleges more than doubled [between 1800 and 1860]", Burke (1982:54) claims. It is a fact that $1.18 \%$ is twice $0.59 \%$ (Table 2.1 ), assuming no error in either number. However, (1) exactly twice is "not more than doubled" (pp. 54) and (2) the increase is $100 \%$, not "at least $200 \%$ " as Burke summarizes. ${ }^{8}$ These kinds of simple arithmetical errors lessen the reader's confidence in the author's ability to handle complex data, especially when other claims he makes are advanced without providing the means to check them.

Third, Burke does not acknowledge that when one is dealing with small numbers, even small errors produce large percentage changes. Burke speaks of a fourteenfold increase in actual enrollments between 1800 and 1860 , a very large expansion. That level of increase is possible in part because the base $\mathrm{N}$ is only 1156 students. Halve that number and the increase would be 28-fold; double the number and the increase drops to 7 fold. Such are the dramatics of percentage change when dealing with small numbers, even when the error is small. Choose an earlier decade, say 1790, and the percent increase probably would be even larger. (After all, "1800" is no more a magical year than "1790.")

A related, major flaw occurs in the discussion of Table 2.1 (and 2.2, 2.3, and many others). Burke fails to report possible errors in both of the critical measures - the enrollment and the census data (white males of age 15-20). Even if they are not large, they are not zero. When one is dealing with small numbers (low of $0.38 \%$ to high of $1.90 \%$ ), small errors produce large variations and make comparisons between values questionable at best. Had mid-points (or any other points) instead of onset of decades been used, would the shifts remained be the same? We do not know.

Like Angelo, Burke has introduced many social factors to explain numerical 
differences that may be nothing more than random fluctuations within a reasonable margin of error. In addition, he has done so without recognizing and/or telling his reader that such is the case. We consequently lose faith in the hypotheses, even if there may have been important forces for explaining what was happening to enrollments. ${ }^{9}$

In summary, these two revisionists are building their cases on the analysis of quantifiable information. It appears as if they should attend more carefully to the treatment of their data, especially with regard to sampling and the consideration of error terms. They also could benefit all of us if they would use more of the readily available sophisticated statistical techniques. For example, it seems clear that Angelo had access to adequate data to treat one curriculum (say medicine) continuously over time. By time series analysis he could determine if there were eras that could be set by statistically significant differences in student populations rather than by selecting them as he did, by eyeballing of improperly plotted graphs. ${ }^{10}$

\section{Discussion}

Although there are flaws in data and in analysis by some of the revisionists, it appears the traditionalists, too, have patched together bits of dubious evidence to support an invalid conclusion, namely, that there was an epidemic of college failures. They write with unquestioned authority and convincingly. If there are any doubts in their minds about their explanations, they do not let the reader in on their reservations. Seldom do they entertain alternative hypotheses.

The revisionists, on the other hand, seem somewhat more attentive to the validity of evidence. They write with a bit more caution, with a "perhaps" or a "maybe" prefacing or qualifying their interpretations of the data. We worry, however, that they have rushed to explain before verifying data and completing analyses that could be made, ones that might significantly affect key relationships. Like Katz (1968) and his classical work on the vote for the Beverly high school in Massachusetts and his analysis based on a couple of bivariate relationships, nearly two decades passed before Vinovskis (1985) employed a multivariate technique on the same data. He found Katz seriously in error. Katz had prematurely halted the analysis.

In the same way that the revisionists charge the traditionalists with looking at the historical record from a biased perspective and finding only what they need to support their case, so too are the revisionists open to the identical charge, one that has already been leveled by Metzger (1984). The argument for both sides depends heavily on how one defines a surviving institution. No doubt this decision is also affected by the relative ease or difficulty that existed 
for a group to acquire a charter to found a college, a process that could well differ both over time and from state to state. The situation is more complex than either side seems to recognize. In this instance the burden of proof for establishing the facts falls heavier on the revisionists. In their desire to set the record "right," we fear they too may be advancing questionable "truths." The revisionists need to refine their skills for verifying and treating data. We do not need to replace old errors with new ones.

Other work, of course, remains to be done. This article is not the place or the occasion to enumerate the kinds of investigations that deserve the highest priority. Many are suggested by the chapter authors in a recent AERA monograph (Best, 1983). Questions like those raised by Mattingly (1983) regarding Vesey's history is a good case in point. In addition, there are debatable questions of what writers of either pursuasion have proved. For example, when Kimball (1986a; 1986b) weighs the evidence, he finds the revisionists not only come up short; he also believes they are documenting the traditionalist position that what transformed the American college into its contemporary university essentially took place after 1865 , not before.

Finally, with respect to the evolution of higher education in the United States, it was anything but monolithic. There were not a handful of leaders whom all strived to imitate, the Riesman serpentine metaphor of the long body (of colleges) wiggling in response to every shift of a small head. Also, it does not look as if there was a rational, education decision to abandon the faculty psychology based on any scientific evidence or an alternative, demonstrated theory of learning.

In the history of U.S. higher education, it appears as if there were some good leaders and some poor ones. No doubt all wanted success and status, survival and growth. Some colleges were better located than others, in communities that became towns and cities of sufficient population to support a college. It seems as if it was the rule rather than the exception for a college to respond to the needs of potential clients and society. The classical curriculum was chipped away, and changes were justified afterwards on "educational grounds."

In the nineteenth century the world's body of knowledge was increasing at an exponential rate, and nothing could stop its growth. Disciplines split by meiosis, inevitably. Specializations spawned subspecializations. No one could unify knowledge anymore, even supposing that knowledge is actually one, a debatable assumption. With the division of knowledge and the need for specialized expertise, an elective system was inevitable, not because of a new psychology of learning (student interest being necessary). Rather, scholarly experts had to have students. Hence students had to be able to choose and not simply comply with a nonalterable set of sourses. Ergo, an elective system emerges, one which has existed ever since, indeed with variations and rises and falls, but never a 
disappearance. (There is always an exception or two, e.g., St. John's College in Annapolis.)

The concluding paragraphs, of course, contain only an hypothesis. Our view is that what happened and why are still open questions. Neither the traditionalist nor the revisionists have a clear case. There is exciting work awaiting historians of higher education.

\section{Notes}

1. In order to highlight the differences between the traditionalists and the revisionists in a restricted space, we have selected quotations which draw starker contrasts between the opposing points of view than one typically finds. There are authors on both sides of the controversy who have tempered the sharp reliefs we have sketched.

2. It may be that the traditionalists have created explanations for an erroneous outcome. Any evidence, no matter how incomplete and inaccurate, that would support their explanations then takes on the status of truth. If this has happened, we have before use a fair amount of history whose truth value is suspect or, at best, unknown.

3. What kind of a case could be made for other disciplines is not known. The branches of the social sciences (economics, anthropology, political science) form professional organizations later in the century.

4. This explanation for a wider social mix of students than the traditional historians have claimed, of course, would not be adequate for western colleges, for few young males there suffered from no opportunity to work. At the same time, there could hardly have been an appreciable frontier "leisure class" and hence the student bodies are likely to have been socially mixed in these colleges.

5. Apparently not, for footnote 2 (p. 262) states that "the Penn sample was assembled by drawing names from the [annual commencement] programs on a fixed percentage basis across all curricula for groups of consecutive years.

6. Burke has given us more quantitative data than all historians and sociologists of higher education combined. We are indebted to his ingenuity, his doggedness, and the countless hours he has labored.

7. On the other hand, Luker (1983) proceeds in his interpretation of problems besetting midwestern religious based colleges on a complete acceptance of Tewksbury's claims. ("Tewksbury Revisited: The Second Great Awakening, Evangelism, Revivalism and Denominationalism in the Founding of Western Colleges, 1790-1860." Symposium paper, annual AERA meeting, Montreal, April, 1983).

8. Angelo's and Burke's errors are different. The former is from sampling (although there is no doubt that there are measurement errors in his as well); the latter is from measurement. These errors, as well as others, exist in both papers.

9. Burke also did not directly address Wayland's claim. Larger numbers of $15-20$ year white males in college do not mean higher enrollments per college unless the number of colleges increases at a lower rate than the number of persons, a critical matter Burke does not discuss. Also, what may be true "on the average" is not likely to be true for every college. Some could be shrinking, and were, as Burke himself reports.

10. The non-quantitative revisionists also need to have their data validated. We have not undertaken such critiques. 


\section{References}

Allmendinger, David F. (1975). Paupers and Scholars: The Transformation of Student Life in 19th Century New England. New York: St. Martin's Press.

Angelo, Richard. "The Social Transformation of American Higher Education." Jarausch, K. H. (ed.), (1983). The Transformation of Higher Learning, 1860-1930. Chicago: University of Chicago Press, pp. 261-292.

Axtell, James. (1971). "The Death of the Liberal Arts College." History of Education Quarterly, vol. 11, Winter, pp. 339-352.

Barnes, Sherman B. (1960). "Learning and Piety in Ohio Colleges, 1865-1900.” Ohio Historical Quarterly, vol. 69, no. 4, October, pp. 327-352.

Best, John H. (ed.) (1983). Historical Inquiry in Education: A Research Agenda. Washington, D.C.: American Educational Research Association.

Boyer, Ernest L. and Levine, Arthur. (1981). A Quest for Common Learning: The Aims of General Education. Washington, D.C.: The Carnegie Foundation for the Advancement of Teaching, n.d.

Bonowman, Merle. (1961). "The False Dawn of The State University." History of Education Quarterly, 1 ( $\# 2)$ : 6-22.

Burke, Colin B. (1973). "The Quiet Influence: The American Colleges and Their Students, 1800-1960." Unpublished Ph.D. dissertation, Washington University.

Burke, Colin. (1982). American Collegiate Population: A Test of the Traditional View. New York: New York University Press.

Butts, Freeman A. and Cremin, Lawrence A. (1953). A History of Education in American Culture. New York: Henry Holt.

Chisolm, Linda A. (1982). "The Art of Undergraduate Teaching in the Age of the Emerging University." Unpublished Ph.D. dissertation, Columbia University.

Creutz, Alan. (1980). "From College to University Scholar: The Evolution of the Faculty at the University of Michigan, 1850-1900." Unpublished Ph.D. dissertation, University of Michigan.

Dominick, Charles A. "A History of Selected Private Colleges in Ohio," Ph.D. dissertation (in progress), University of Michigan.

Findlay, James (1982). "Western Colleges, 1830-1870: Education Institution in Transition." History of Higher Education Annual, 2: 35-64.

Flexner, Abraham. (1908). "The American College: A Criticism." New York: Arno Press.

Guralnick, Stanley, M. (1974). "Sources of Misconception on the Role of Science in the Nineteenth Century American College.” Isis, vol. 65, pp. 48-62.

Haddad, Gladys Marylin. (1980). "Social Roles and Advanced Education for Women in Nineteenth Century America: A Study of Three Western Reserve Institutions." Unpublished Ph.D. dissertation, Case Western Reserve University.

Herbst, Jurgen. (1968). Review of Burke, Higher Education 12 (August, 1983): 484-485.

Katz, Michael. (1980). The Irony of Early School Reform: Educational Innovation in MidNineteenth Century Massachusetts, Cambridge. Maris A. Vinovskis, "The Politics of Education Reform in Nineteenth Century Massachusetts: The Controversy over the Beverly High School in 1860," ERIC (ED 200495).

Kennedy, Sister M. St. Mel., O.S.F. (1961). "The Changing Academic Characteristics of the Nineteenth Century American College Teacher." Unpublished Ph.D. dissertation, St. Louis University.

Kimball, Bruce A. (1986a). "Essay Review: History of Higher Education Annual: vols. 1-4, 1981-1984." History of Higher Education Annual, 5.

Kimball, Bruce A. (1986b). "Paradoxes of Inclusivism in Retelling the History of the American College." Minerva. 
Mattingly, Paul H. (1983). "Structures Over Time: Institutional History,” In: Best, John H. (ed.). Historical Inquiry in Education: A Research Agenda. Washington, D.C.: American Educational Research Association, pp. 34-55.

McCaughey, Robert A. (1974). "The Transformation of American Academic Life: Harvard University, 1821-1892," Perspectives in American History, Vol. 8, pp. 239-332.

Metzger, Walter P., (1984). Review of Burke, Journal of Higher Education (55): 421.

Naylor, Natalie. (1973). "The Ante-Bellum College Movement: A Reappraisal of Tewksbury's Founding of American Colleges and Universities." History of Education Quarterly. Vol. 260, Fall, pp. 261-274.

Palmer, Barbara Heslan. (1980). "Lace Bonnets and Academic Gowns: Faculty Development in Four Women's Colleges, 1875-1915." Unpublished Ph.D. dissertation, Boston College.

Peterson, George E. (1964). The New England College in the Age of the University. Amherst, Mass.: Amherst College Press.

Potts, David B. (1971). "American Colleges in the Nineteenth Century: From Localism to Denominationalism." History of Education Quarterly, vol. 11, Winter, pp. 363-380.

Potts, David B. (1977). "'College Enthusiasm!' As Public Response, 1800-1860." Harvard Educational Review, vol. 47, no. 1, February, pp. 28-42.

Rogers, Walter P. (1942). Andrew White and the Modern University. Ithica, New York: Cornell University Press.

Rudolph, Frederick. (1962). The American College and University. New York: Knopf.

Schmidt, George P. (1957). The Liberal Arts College: A Chapter in American Cultural History. New Brunswick, N.J.: Rutgers University Press.

Sloan, Douglas. (1971). "Harmony, Chaos, and Consensus: The American College Curriculum." Teachers College Record, vol. 73, no. 2, December, pp. 221-257.

Tewksbury, Donald G. (1932). The Founding of American Colleges and Universities. New York: Teachers College Press.

Tobias, Marilyn. (1982). Old Dartmouth on Trial: The Transformation of the Academic Community in Nineteenth Century America. New York: New York University Press.

Veysey, Laurence R. (1965). The Emergence of the American University. Chicago: University of Chicago Press.

Vinovskis, Maris A. (1985). The Origins of Public High Schools: A Re-Examination of the Beverly High School Controversy. Madison: University of Wisconsin Press. 